\title{
Structure of a Rhodococcus gene encoding pigment production in Escherichia coli
}

\author{
StePhen HaRT, RalPh KirbY and David R. WoOds* \\ Department of Microbiology, University of Cape Town, Rondebosch 7700, South Africa
}

(Received 26 January 1990; revised 27 March 1990; accepted 2 April 1990)

\begin{abstract}
A 2.1 kbp DNA fragment from Rhodococcus strain ATCC 21145 gave rise to the production of blue and pink pigments in Escherichia coli when cloned downstream of a strong promoter. The sequence of this DNA fragment contains a single open reading frame with a putative ribosome-binding site, potentially coding for a single protein of $M_{\mathrm{r}} 42560$. Deletion analysis and in vitro transcription-translation experiments support the hypothesis that pigment production in $E$. coli is due to a single enzyme whose catalytic activity is still unknown. This small pigment gene may become useful for the development of a new generation of chromogenic cloning vectors which do not require expensive substrates for the detection of gene expression.
\end{abstract}

\section{Introduction}

Recently we reported the cloning and expression in Escherichia coli of pigment-producing genes from two strains of the nocardioform actinomycete Rhodococcus (Hill et al., 1989). Initially, grey-blue $E$. coli colonies were detected which contained DNA from the buff-coloured Rhodococcus ATCC 21145 and the coral-coloured Rhodococcus sp. JL10. The pigments were analysed and found to contain blue and pink components, neither of which could be detected in the Rhodococcus strains. Introduction of the same DNA into the unpigmented actinomycete Streptomyces griseus did not result in pigment production. The preliminary chemical characterization of the pink and blue pigments indicated that they were different from the prodigiosin-like and actinorhodin-like pigmented compounds commonly produced by actinomycetes (Gerber \& Lechevalier, 1976; Rudd \& Hopwood, 1980; Tsao et al., 1985).

Since the production of pigment by a Rhodococcus gene in $E$. coli is interesting, and as nocardioform genes have not yet been well studied, we determined the structure of the pigment gene from Rhodococcus ATCC 21145. Knowledge of the DNA sequence of the pigment gene will facilitate its development as a chromogenic

Abbreviations: Ap, ampicillin; Lac, $\beta$-galactosidase; ORF, open reading frame; Pig, pigment production; TBE, tris/borate/EDTA; Tc, tetracycline, Ts, thiostrepton.

The nucleotide sequence data reported in this paper have been submitted to GenBank and have been assigned the accession number M30195. vector which does not require an expensive substrate (e.g. X-Gal).

\section{Methods}

Bacterial strains, plasmids and media. The $E$. coli strain LK111 was used in all experiments (K514 derivative; lacI lacZ $\Delta \mathrm{M} 15$ lac $Y^{+}$) (Zabeau \& Stanley, 1982). The plasmids used are listed in Table 1. Plasmids were designated $\mathrm{Pig}^{+}$or $\mathrm{Pig}^{-}$depending on whether they could or could not produce pigment in E. coli. E. coli LK 111 containing pUC and 'Bluescript'-derived plasmids were grown in Luria-Bertani (LB) medium (Maniatis et al., 1982) containing ampicillin (Ap) $(100 \mu \mathrm{g}$ $\mathrm{ml}^{-1}$ ). Transformants containing derivatives of pMC1871 were selected on LB agar containing tetracycline (Tc) $\left(12.5 \mu \mathrm{g} \mathrm{ml}^{-1}\right), \mathrm{X}-\mathrm{Gal}$ $\left(40 \mu \mathrm{g} \mathrm{ml}^{-1}\right)$ and IPTG $\left(12 \mu \mathrm{g} \mathrm{ml}^{-1}\right)$, or on lactose MacConkey agar containing Tc $\left(12 \cdot 5 \mu \mathrm{g} \mathrm{ml}^{-1}\right)$.

Preparation of plasmid DNA. Plasmid DNA was prepared from $E$. coli LK111 by the alkaline-lysis method of Ish-Horowicz \& Burke (1981). Large-scale preparations were purified by $\mathrm{CsCl}$ equilibrium gradient centrifugation (Maniatis et al., 1982).

Subcloning and restriction fragment deletion procedures. Restriction endonucleases (Boehringer-Mannheim, Anglian Biotechnology or BRL) were used as described by Maniatis et al. (1982). Digested DNA fragments were gel-purified by electrophoresis in low-melting-point agarose gels (Seaplaque or BRL). DNA fragments were either excised and ligation reactions performed in the resolidified agar (Struhl, 1985), or they were separated from the agarose with 'Geneclean' (Bio 101, California, USA) according to the manufacturer's instructions. Klenow fragment of DNA polymerase I (Boehringer-Mannheim) was used to generate blunt-ended restriction fragments (Maniatis et al., 1982). Ligations were performed with T4 DNA ligase (BoehringerMannheim) in a buffer containing $50 \mathrm{mM}$-Tris/HCl, pH 7.6, $10 \mathrm{mM}$ $\mathrm{MgCl}_{2}, 1 \mathrm{mM}$-DTT and $1 \mathrm{mM}$-ATP. Self-ligation of the vector plasmids was prevented by treatment with calf intestinal alkaline phosphatase (Boehringer-Mannheim) (Tabor, 1987). Competent E. coli cells were 
Table 1. Description of plasmids

\begin{tabular}{|c|c|c|}
\hline Plasmid & Phenotype & Reference \\
\hline 'Bluescript' KS & $\mathrm{Ap}^{\mathrm{r}} \mathrm{Lac}^{+}$ & Stratagene, San Diego, USA \\
\hline pBSLacl & Tet $^{r} \mathrm{Lac}^{-}$ & \\
\hline pHSLacl & Tet $^{r} \mathrm{Lac}^{+}$ & This study \\
\hline pKS1 & $\mathrm{Ap}^{r} \mathrm{Lac}^{-} \mathrm{Pig}^{+}$ & \\
\hline pKS3 & $\mathrm{Ap}^{r} \mathrm{Lac}^{-} \mathrm{Pig}^{+}$ & \\
\hline pMC1871 & Tet $^{\mathrm{r}} \mathrm{Lac}^{-}$ & Casadaban (1984) \\
\hline pNC181 & $\mathrm{Ap}^{\mathrm{r}} \mathrm{Lac}^{-} \mathrm{Pig}^{+}$ & \\
\hline $\mathrm{pNC} 184$ & $\mathrm{Ap}^{r} \mathrm{Lac}^{-} \mathrm{Pig}^{-}$ & \\
\hline pNC185 & $\mathrm{Ap}^{r} \mathrm{Lac}^{-} \mathrm{Pig}^{+}$ & \\
\hline pNC186 & $\mathrm{Ap}^{\mathrm{r}} \mathbf{L a c}^{-} \mathrm{Pig}^{-}$ & This study \\
\hline pNC191 & $\mathrm{Ap}^{\mathrm{r}} \mathrm{Lac}^{-} \mathrm{Pig}^{+}$ & \\
\hline pNC192 & $\mathrm{Ap}^{\mathrm{r}} \mathrm{Lac}^{-} \mathrm{Pig}^{+}$ & \\
\hline $\mathrm{pNC194}$ & $\mathrm{Ap}^{\mathrm{r}} \mathrm{Lac}^{-} \mathrm{Pig}^{+}$ & \\
\hline pNIL260 & $\mathrm{Ap}^{\mathrm{r}} \mathrm{Ts}^{\mathrm{r}} \mathrm{Pig}^{+}$ & Hill et al. (1989) \\
\hline pNIL270 & $\mathrm{Ap}^{\mathrm{r}} \mathrm{Ts}^{\mathrm{r}} \mathrm{Pig}^{-}$ & This study \\
\hline pUC18 & $\mathrm{Ap}^{\mathrm{r}} \mathrm{Lac}^{+}$ & Vieira \& Messing (1982) \\
\hline pUC19 & $\mathrm{Ap}^{\mathrm{r}} \mathrm{Lac}^{+}$ & \\
\hline
\end{tabular}

prepared and transformed by the method of Chung \& Miller (1988). Electrophoresis of DNA restriction digests was performed in $0.8 \%$ agarose gels in $1 \times$ TBE buffer (Maniatis et al., 1982).

DNA sequencing. DNA was prepared for sequencing by the construction of ordered deletions using exonuclease III (BoehringerMannheim) (Henikoff, 1984) from two of the shortest pigmentproducing plasmids $\mathrm{pKS} 1$ and $\mathrm{pKS} 3$, and plasmids containing upstream DNA sequences (Fig. 1). DNA sequencing was done by the dideoxy chain-terminating method of Sanger et al. (1977) with a 'Sequenase' kit (US Biochemicals Corp.). The DNA was radiolabelled with $\left[{ }^{35}\right.$ S $]$ dATP $\left[>1000 \mathrm{Ci}(37 \mathrm{kBq}) \mathrm{mmol}^{-1}\right]$ (Amersham, UK). The nucleotide sequences were analysed with an IBM XT computer, using the DNA Tools and Genepro (version 3.1) programs. A BASIC program based on the non-random distribution of $G$ and $C$ nucleotides in codons used by bacteria with a high $G+C$ content (Bibb et al., 1984) was used to identify potential open reading frames (ORFs) (R. Kirby, personal communication). Deduced amino acid sequences were analysed and compared by using the data bases of GenBank (release 60.0, 6/89) and EMBL (modified) (release 19.0, 5/89).

Construction of lac fusions. The HindIII/SmaI and Bg/II/SmaI fragments of pNC192 were subcloned into the SmaI site of pMC1871 to give in-frame fusions to the lac $Z$ gene of $\mathrm{pMC1871.} \mathrm{Successful} \mathrm{fusions}$ were detected on LB-Tc plates containing X-Gal, confirmed by DNA sequencing and subsequently tested for transcriptional promoter activity on lactose MacConkey plates containing Tc.

In vitro transcription-translation. A prokaryotic DNA-directed in vitro transcription and translation kit (Amersham, UK) was used, according to the manufacturer's instructions for the in vitro transcription and translation of plasmid DNA. L- $\left[{ }^{35}\right.$ S $]$ Methionine [ $>1000 \mathrm{Ci}$ (37 $\mathrm{kBq}$ ) $\mathrm{mmol}^{-1}$ ] (Amersham, UK) was used as the radiolabelled amino acid. The labelled proteins were separated by electrophoresis in a $15 \%$ (w/v) polyacrylamide gel containing $0.1 \%$ SDS by the method of Laemmli (1970). High molecular weight standards $\left(M_{\mathrm{r}} 18500-330000\right)$ (Pharmacia) were used to estimate the size of labelled proteins.

\section{Results}

\section{Restriction fragment deletions and subclonings}

The pigment-producing plasmid pNIL260 (Fig. 1) was shortened to obtain smaller $\mathrm{Pig}^{+}$plasmids. Subcloning the HindIII/EcoRV fragment of pNIL260 into pUC18 and pUC19 produced the $\mathrm{Pig}^{+}$plasmids $\mathrm{pNC} 181$ and pNC191 respectively, which contained the insert DNA in both orientations relative to the lacOP promoter of pUC18 and pUC19 (Fig. 1). Plasmid pNC191 produced more pigment in $E$. coli cells than pNC181, and pNC191 contained the $\mathrm{Pig}^{+} \mathrm{DNA}$ insert in the correct orientation to the lacOP promoter of pUC19. However, pigment production by $\mathrm{pNC181}$ suggested that the $\mathrm{Pig}^{+} \mathrm{DNA}$ insert had its own promoter. Deletion of the SmaI/ EcoRV fragment of pNIL260 resulted in pNIL270, which did not produce pigment in E. coli cells (Fig. 1).

The plasmid pNC192 was generated by deletion of a small EcoRI fragment from pNC191, and the $1.8 \mathrm{kbp}$ $S p h \mathrm{I} / E c o \mathrm{RI}$ fragment of pNC192 was then subcloned into pUC18 and pUC19 to generate the plasmids pNC184 and pNC194 respectively. Pigment production from pNC194 was the same as from pNC191 and pNC192 but pNC184-containing transformants were not pigmented. This observation suggested that the coding sequence of the enzyme or enzymes responsible for pigment production lay between the $S p h \mathrm{I}$ and $E c o$ RI sites of the Rhodococcus DNA insert and that the putative promoter lay between the HindIII and SphI sites of $\mathrm{pNC181.}$

Plasmids pNC185 and pNC186 were made by subcloning the $B g l \mathrm{II}$ fragment of pNC192 into the BamHI site of pUC18. The insert of pNC185 was Pig ${ }^{+}$ and was in the correct orientation to the lacOP promoter of pUC18 whereas the insert of pNC186 was in the reverse orientation and was $\mathrm{Pig}^{-}$. This result suggested that promoter activity originates from between the $H$ indIII and BglII sites in the vector part of $\mathrm{pNC} 181$.

The plasmid pKS1 was prepared by subcloning the $S p h \mathrm{I} / E c o$ RI fragment of pNC192 into 'Bluescript' KS in the correct orientation to the lacOP promoter. pKS3 was made by deleting the $B g I I / / B a m H I$ fragment at the $3^{\prime}$ end of the pKS1 insert. Both plasmids were $\mathrm{Pig}^{+}$.

\section{Nucleotide sequencing}

The 2109 bp BglII fragment which was capable of pigment production (in plasmid pNC186) was sequenced in both directions. A large open reading frame (ORF) of $1653 \mathrm{bp}$ was detected which began with a methionine ATG codon at position 299 of the 2109 bp sequence (Fig. 2). Five other in-frame methionine ATG codons were present at positions $305,458,581,791$ and 815 within the ORF. Since long stretches of open reading frame occur randomly in bacteria with a high $\mathrm{G}+\mathrm{C}$ content, presumably due to the lack of $A$ and $T$ nucleotides which are a predominant feature of termination codons, additional evidence is necessary to assign the correct start codons in such organisms. The smallest $\mathrm{Pig}^{+}$ 

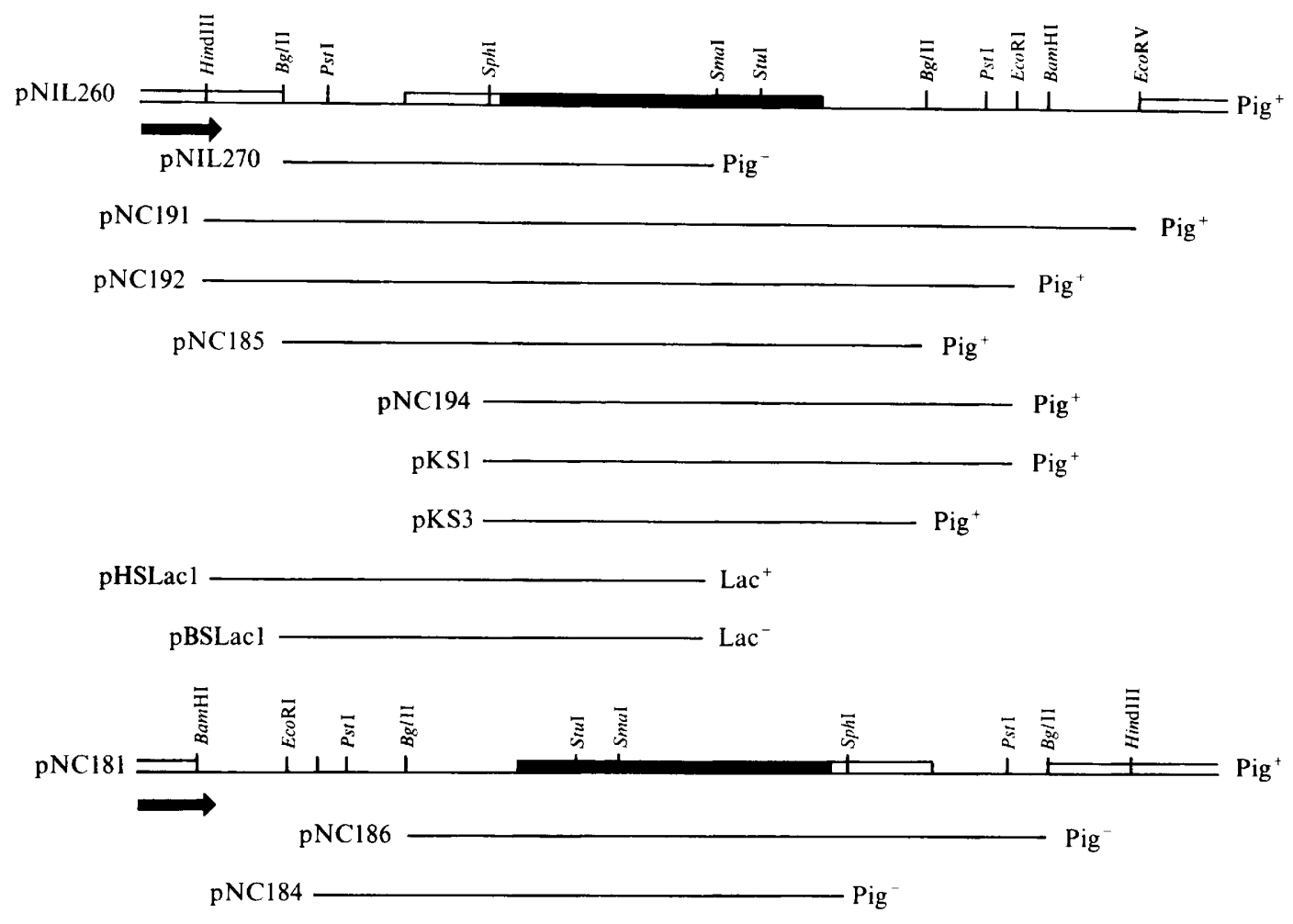

$\stackrel{100 \mathrm{bp}}{\longmapsto}$

Fig. 1. Restriction maps of plasmids used in the analysis and sequencing of the pigment gene. The following plasmids were derived from pNIL260: pNIL270 $\left(\mathrm{Pig}^{-}\right)$, deletion of SmaI/EcoRV fragment; pNC181 ( $\left.\mathrm{Pig}^{+}\right)$and pNC191 $\left(\mathrm{Pig}^{+}\right)$, HindIII/EcoRV fragment of pNIL260 subcloned into pUC18 and pUC19 respectively; pNC192 ( ig $\left.^{+}\right)$, deletion of $3^{\prime}$ end of pNC191 up to EcoRI site; pNC184 $\left(\mathrm{Pig}^{-}\right)$and $\mathrm{pNC} 194\left(\mathrm{Pig}^{+}\right)$, SphI/EcoRI fragment $(1.5 \mathrm{kbp})$ of pNC191 subcloned into pUC18 and pUC19 respectively; $\mathrm{pNC}^{2} 185$ (Pig $\left.{ }^{+}\right)$

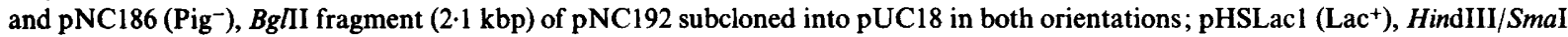
fragment (1.6 kbp) in pMC1871 lac fusion; pBSLac1 $\left(\mathrm{Lac}^{-}\right)$, BglII/SmaI fragment (1.4 kbp) in pMC1871 lac fusion. Arrows denote direction of transcription from lacOP. Flanking open boxes indicate vector sequences; lines indicate insert Rhodococcus DNA; solid boxes indicate probable coding region and attached open boxes represent the rest of the ORF.

subclones, pKS1 and pKS3, contained inserts of $1.8 \mathrm{kbp}$ and $1.5 \mathrm{kbp}$ respectively and neither contained the first four ATG codons at positions 299, 305, 458, and 581 within the ORF. However, both pKS1 and pKS3 produced pigment in $E$. coli cells. This suggested that the translation initiation codon was at either position 791 or 815. The purine-rich sequence, GGAGGAAA- - -ATG, $^{-}$ preceding the ATG codon at position 791 was a possible ribosome-binding site (Shine \& Dalgarno, 1974). The ATG methionine codon at position 815 was not preceded by a purine-rich sequence.

The ORF was terminated by a TGA stop codon which was separated by $39 \mathrm{bp}$ from a second TAA stop codon. An 8 bp stem, 4 base loop structure $[\Delta G=-14.0 \mathrm{kcal}$ $\mathrm{mol}^{-1}\left(-58.6 \mathrm{~kJ} \mathrm{~mol}^{-1}\right)$, calculated by the method of Salser $e$ et al. (1977)] was present 78 bp downstream from the first stop codon. This stem-loop structure was followed by only two $\mathrm{T}$ nucleotides. Rho-independent termination sequences in $E$. coli normally contain at least four $T$ nucleotides after the stem-loop structure (Rosenberg \& Court, 1979; Trifonov \& Brendel, 1987).

\section{Codon usage and the $O R F$}

The G+C content of the Rhodococcus DNA ORF extending from the ATG methionine start codon at position 791 was $67.3 \mathrm{~mol} \%$. It has previously been established that bacterial species such as Streptomyces which have a high $\mathrm{G}+\mathrm{C}$ content show a strong bias towards the use of $\mathrm{G}$ or $\mathrm{C}$ in the third or 'wobble' position of their codons (Bibb et al., 1984). A low $G+C$ content at the second position and an intermediate $G+C$ level at the first position is also characteristic of the codon usage pattern of bacteria with a high $\mathrm{G}+\mathrm{C}$ content 


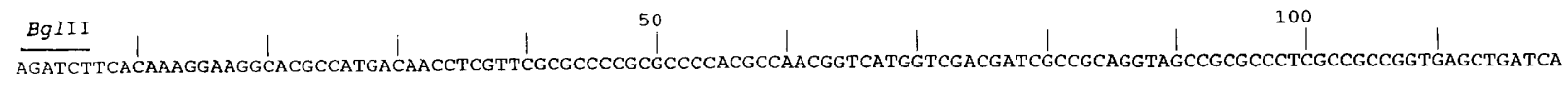

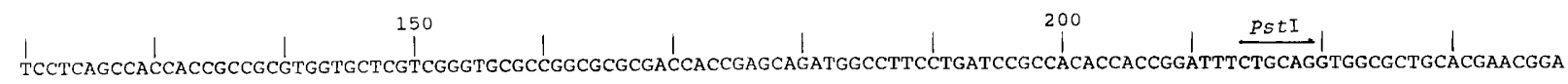

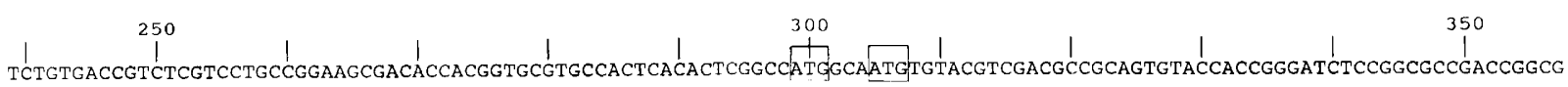

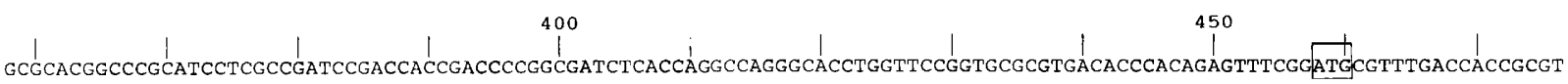

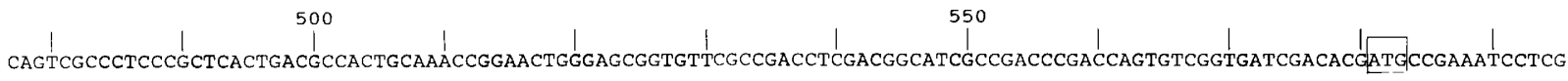

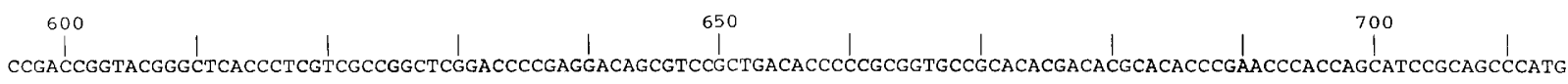

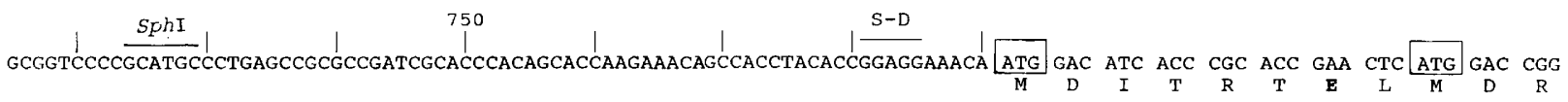


Table 2. Codon usage in the protein-coding region from position $791 \mathrm{bp}$ to $1954 \mathrm{bp}$

\begin{tabular}{lrrlllllllll}
\hline \hline TTT & Phe & 1 & TCT & Ser & 0 & TAT & Tyr & 1 & TGT & Cys & 0 \\
TTC & Phe & 17 & TCC & Ser & 7 & TAC & Tyr & 9 & TGC & Cys & 1 \\
TTA & Leu & 0 & TCA & Ser & 1 & TAA & $* * *$ & 0 & TGA & $* * *$ & 1 \\
TTG & Leu & 2 & TCG & Ser & 5 & TAG & $* * *$ & 0 & TGG & Trp & 6 \\
& & & & & & & & & & & \\
CTT & Leu & 0 & CCT & Pro & 0 & CAT & His & 0 & CGT & Arg & 5 \\
CTC & Leu & 19 & CCC & Pro & 11 & CAC & His & 5 & CGC & Arg & 12 \\
CTA & Leu & 0 & CCA & Pro & 0 & CAA & Gln & 2 & CGA & Arg & 0 \\
CTG & Leu & 15 & CCG & Pro & 11 & CAG & Gln & 13 & CGG & Arg & 8 \\
& & & & & & & & & & & \\
ATT & Ile & 1 & ACT & Thr & 0 & AAT & Asn & 2 & AGT & Ser & 1 \\
ATC & Ile & 16 & ACC & Thr & 25 & AAC & Asn & 6 & AGC & Ser & 4 \\
ATA & Ile & 0 & ACA & Thr & 0 & AAA & Lys & 0 & AGA & Arg & 0 \\
ATG & Met & 8 & ACG & Thr & 5 & AAG & Lys & 10 & AGG & Arg & 0 \\
& & & & & & & & & & & \\
GTT & Val & 1 & GCT & Ala & 2 & GAT & Asp & 2 & GGT & Gly & 6 \\
GTC & Val & 14 & GCC & Ala & 33 & GAC & Asp & 26 & GGC & Gly & 12 \\
GTA & Val & 2 & GCA & Ala & 5 & GAA & Glu & 11 & GGA & Gly & 4 \\
GTG & Val & 11 & GCG & Ala & 11 & GAG & Glu & 10 & GGG & Gly & 8 \\
\hline \hline
\end{tabular}

(Bibb et al., 1984). These features of the codon usage pattern have allowed the identification of protein-coding sequences (Bibb et al., 1984).

The complete Rhodococcus DNA sequence was analysed for these codon usage patterns. A non-random distribution of $\mathrm{G}$ and $\mathrm{C}$ nucleotides started at the ATG methionine codon at position $791 \mathrm{bp}$ and continued until the first stop codon (TGA at position $1952 \mathrm{bp}$ ). The overall $\mathrm{G}+\mathrm{C}$ content of the $1161 \mathrm{bp}$ of the ORF starting at position 791 was $67.3 \%$ and that of the first, second and third codon positions was $66.9 \%, 47.3 \%$ and $88.1 \%$ respectively. This nucleotide distribution is typical for bacteria with a high $\mathrm{G}+\mathrm{C}$ content.

The $\mathrm{G}$ and $\mathrm{C}$ distribution in the ten codons preceding the proposed start codon was $60 \%, 50 \%$ and $40 \%$ for the first, second and third positions respectively and $60 \%$, $40 \%$ and $90 \%$ in the ten codons after the proposed start codon. The strong bias towards $\mathrm{G}$ and $\mathrm{C}$ in the third position was only apparent after this start codon and was not observed with the ATG methionine at position 815 . The biased codon usage pattern was centred upon the start codon at position $791 \mathrm{bp}$, supporting the proposal that it was the translation start point.

The pattern of codon usage illustrates the preference for codons ending in $\mathrm{G}$ or $\mathrm{C}$ in the 'wobble' position (Table 2). This was true for all amino acids except glutamic acid, where the codon GAA was used as frequently as GAG. The distribution of the two codons for glutamic acid was polarized; the GAA codon was predominantly utilized at the $5^{\prime}$ end of the protein coding sequence and the GAG codon was preferred towards the $3^{\prime}$ end. It is interesting that the occurrence of the GAA codon was also greater than expected in the only other sequenced Rhodococcus gene, the nitrile hydratase gene (Ikehata et al., 1989).

\section{Deduced amino acid sequence and in vitro transcription- translation}

The deduced amino acid sequence of the $1161 \mathrm{bp}$ coding sequence from the start codon at position 791 consisted of 387 residues, with a calculated $M_{\mathrm{r}}$ of 42056 . The major labelled protein produced in the in vitro transcriptiontranslation experiments by the insert DNA in plasmids pNC192 and pKS3 had an apparent $M_{\mathrm{r}}$ of approximately 42000 (Fig. 3), which agreed well with the predicted $M_{\mathrm{r}}$.

The deduced amino acid sequence of the pigment gene product was compared with other known sequenced proteins using a limitation of 10 matches in a window of 30 residues. However, no significant amino acid sequence similarities were detected.

\section{Upstream DNA sequence and lac fusions}

Orientation of the pigment gene in reverse direction to the lacOP promoter, in $\mathrm{pNC184}$, resulted in the inhibition of pigment production. However, pigment production was reinstated in $\mathrm{pNC181}$, in which the

Fig. 2. Nucleotide sequence of the Rhodococcus pigment gene and deduced amino acid sequence of the ORF. The potential ShineDalgarno sequence is marked as S-D. The first six potential ATG start codons are boxed. The glutamic acid residues, E, are in bold lettering. An inverted complementary repeat sequence is indicated by opposing arrows. The stop codons are indicated by asterisks. 


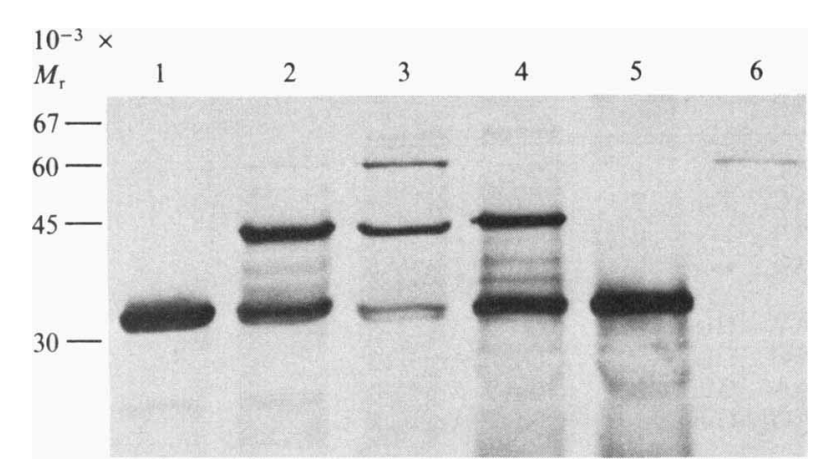

Fig. 3. Autoradiogram of the cell-free coupled transcription-translation polyacrylamide gel. Lanes: 1, 'Bluescript' KS; 2, pKS3; 3, pNC191; 4, pNC185; 5, pUC18; 6, no DNA. The bands at $M_{\mathrm{r}} 31000$ represent $\beta$-lactamase; those at $M_{\mathrm{r}} 42000$ represent the pigment gene product; those at $M_{\mathrm{r}} 60000$ are an artifact of the cell-free transcriptiontranslation system (Amersham).

insert was in the same orientation to the lacOP promoter as that in pNC184, but which contained an additional HindIII/SphI fragment from pNIL260 (Fig. 1). This suggested the presence of a Rhodococcus promoter in the upstream region on pNC181 which could initiate transcription in E. coli. However, the region between the HindIII and the BglII sites was not Rhodococcus DNA but part of the neighbouring vector DNA of pNIL260. The ability of the HindIII/Bg/II fragment of the vector DNA to promote transcription was confirmed by the construction of lac fusions with the promoter-probe vector pMC1871. pBSLacl contained an in-frame lac fusion with the $B g / \mathrm{II} / S m a \mathrm{I}$ fragment of pNC192 and was $\mathrm{Lac}^{-}$. However, the HindIII/SmaI lac fusion in pHSLac1 was $\mathrm{Lac}^{+}$, suggesting that the promoter activity lay in the HindIII/BgIII fragment derived from pNIL260 and not the Rhodococcus DNA insert.

The $B g /$ II fragment of pNC191, which contained the pigment gene and $700 \mathrm{bp}$ of Rhodococcus upstream sequence, was subcloned into the BamHI site of pUC18 in both orientations to the lacOP promoter. The plasmid pNC185, which contained the BglII fragment in the correct orientation for expression from the lacOP promoter, produced large amounts of pigment whereas pNC186, which contained the insert in the reverse orientation to the lacOP promoter, was not pigmented. This indicated, as did the lac fusions, that the Rhodococcus upstream sequence did not contain a promoter which functioned in $E$. coli and that a spurious promoter in the neighbouring vector DNA of pNIL260 was responsible for transcription in $\mathrm{pNC1} 181$.

\section{Discussion}

The nucleotide sequence of the Rhodococcus pigment gene was located within a large ORF of $1653 \mathrm{bp}$.
Although this is a single ORF, the structural gene probably starts with an ATG start codon situated $492 \mathrm{bp}$ downstream of the first ATG of the large ORF. The nucleotide sequence of the pigment structural gene therefore consists of $1161 \mathrm{bp}$ with the coding capacity for a protein of $M_{\mathrm{r}} 42056$. The conclusion that the pigment gene consists of $1161 \mathrm{bp}$ is based on the following evidence: (i) the close agreement between the calculated $M_{\mathrm{r}}$ of the pigment gene product (42056) and the $M_{\mathrm{r}}$ determined by SDS-PAGE (42000); (ii) the asymmetrical distribution of $\mathrm{G}$ and $\mathrm{C}$ nucleotides observed in the codon usage pattern, which allowed the reliable prediction of the protein-coding sequence and the start point of the pigment gene; (iii) the ATG start codon of the 1161 bp sequence is the only ATG of the larger 1653 bp ORF which is preceded by a putative ribosome-binding site; (iv) deletion of the first four ATG codons of the longer $1653 \mathrm{bp}$ ORF did not prevent initiation of translation of the pigment gene mRNA.

The expression of the pigment gene in both orientations in various vectors in $E$. coli initially suggested that the gene was regulated by an upstream sequence of Rhodococcus DNA in E. coli (Hill et al., 1989). However, it was shown that the Rhodococcus upstream DNA sequence did not contain any $E$. coli promoter consensus sequences and was unable to promote the expression of the pigment gene in $E$. coli. Pigment production by $E$. coli cells containing plasmids with the pigment gene inserted in reverse orientation to the lac $O P$ promoter was due to a spurious promoter in the neighbouring vector DNA sequence of pNIL260.

The codon usage for glutamic acid did not show the $\mathrm{G}+\mathrm{C}$ bias in the 'wobble' position which was observed in the codon usage pattern for all other residues. The Glu codons GAA and GAG were present at the same frequency. The bias against the expected greater use of the GAG codon may be to avoid resemblances to the Shine-Delgarno sequence (GAA codons are especially favoured at the $5^{\prime}$ end of the gene). It has been reported that the sequences GAGG and GGAG, which are contained in the Shine-Dalgarno sequence, appear infrequently in the coding region of prokaryotes (Shpaer, 1986).

Hill et al. (1989) reported that the Rhodococcus DNA insert sequenced in this study caused production of both blue and pink pigments in $E$. coli. The nucleotide sequence of the smallest DNA fragments which gave rise to the pigments indicated that a single Rhodococcus gene product was involved in the biosynthesis of these pigments. The pigment gene product appears to be a novel protein since no amino acid homology was detected with other known protein sequences in the GenBank and EMBL data bases.

The small size of the pigment gene suggests its 
application for the development of chromogenic vectors for detection of cloned inserts by insertional inactivation, for promoter-probe vectors and for other instances where reporter genes find application. An advantage of vectors based on this pigment gene is that no expensive substrates, such as $\mathrm{X}$-Gal, are required.

\section{References}

BibB, M. J., Findlay, P. R. \& Johnson, M. W. (1984). The relationship between base composition and codon usage in bacterial genes and its use for the simple and reliable identification of protein-coding sequences. Gene 30, 157-166.

Casadaban, M. J., Martinez-Arias, A., Shapira, S. K. \& Chou, J. (1984). $\beta$-Galactosidase gene fusions for analysing gene expression in Escherichia coli and yeast. Methods in Enzymology 100, 293-308.

ChUNG, C. T. \& MilleR, R. H. (1988). A rapid and convenient method for the preparation and storage of competent cells. Nucleic Acids Research 16, 3580.

Gerber, N. N. \& Lechevalier, M. P. (1976). Prodiginine (prodigiosin-like) pigments from Streptomyces and other aerobic actinomycetes. Canadian Journal of Microbiology 22, 658-667.

HENIKOFF, S. (1984). Unidirectional digestion with exonuclease III creates targeted breakpoints for DNA sequencing. Gene 28, 351-359.

Hill, R., HART, S., Illing, N., KiRBY, R. \& Woods, D. R. (1989). Cloning and expression of Rhodococcus genes encoding pigment production in Escherichia coli. Journal of General Microbiology 135, $1507-1513$.

Ikehata, O., Nishiyama, M., Horinouchi, S. \& Beppu, T. (1989). Primary structure of nitrile hydratase deduced from the nucleotide sequence of a Rhodococcus species and its expression in Escherichia coli. European Journal of Biochemistry 181, 563-570.

IsH-HoRowiCZ, D. \& BurKe, J. F. (1981). Rapid and efficient cosmid cloning. Nucleic Acids Research 9, 2989-2998.

LAEMMLI, U. K. (1970). Cleavage of structural proteins during assembly of the head of bacteriophage T4. Nature, London 227, 680685 .
Maniatis, T., Fritsch, E. F. \& Sambrook, J. (1982). Molecular Cloning : a Laboratory Manual. Cold Spring Harbor, New York: Cold Spring Harbor Laboratory.

ROSENBERG, M. \& COURT, D. (1979). Regulatory sequences involved in the promotion and termination of RNA transcription. Annual Review of Genetics 13, 319-353.

RuDD, B. A. M. \& Hopwood, D. A. (1980). A pigmented mycelial antibiotic in Streptomyces coelicolor: control by a chromosomal gene cluster. Journal of General Microbiology 119, 333-340.

SALSER, W. (1977). Globin mRNA sequences: analysis of base pairing and evolutionary implications. Cold Spring Harbor Symposia on Quantitative Biology 42, 985-1002.

SANGer, F., Nicklen, S. \& Coulson, A. R. (1977). DNA sequencing with chain-terminating inhibitors. Proceedings of the National Academy of Sciences of the United States of America 74, 5463-5467.

ShINe, J. \& Dalgarno, L. (1974). The 3'-terminal sequence of Escherichia coli $16 \mathrm{~S}$ ribosomal RNA: complementarity to nonsense triplets and ribosome binding sites. Proceedings of the National Academy of Sciences of the United States of America 71, 1342-1346.

SHPAER, E. G. (1986). Constraints on codon context in Escherichia coli genes. Their possible role in modulating the efficiency of translation. Journal of Molecular Biology 188, 555-564.

STRUHL, K. (1985). A rapid method for creating recombinant DNA molecules. BioTechniques 3, 452-453.

TABOR, S. (1987). Phosphatases and kinases. In Current Protocols in Molecular Biology, pp. 3.10.1-3.10.2. Edited by F. M. Ausubel, R. Brent, R. E. Kingston, D. D. Moore, J. G. D. Seidman, J. A. Smith \& K. Struhl. New York: Greene Publishing Associates \& WileyInterscience.

Trifonov, E. M. \& Brendel, V. (1987). Gnomic: a Dictionary of Genetic Codes, pp. 258-259. New York: VCH Publishers.

Tsao, S.-W., Rudd, B. A. M., He, D.-G., Chang, C.-J. \& Floss, H. G. (1985). Identification of a red pigment from Streptomyces coelicolor A3(2) as a mixture of prodigiosin derivatives. Journal of Antibiotics $38,128-131$.

Vieira, J. \& Messing, J. (1982). The pUC plasmids, an M13mp7derived system for insertion mutagenesis and sequencing with synthetic universal primers. Gene 19, 259-268.

ZABEAU, M. \& STANLEY, K. (1982). Enhanced expression of cro- $\beta$ galactosidase fusion proteins under the control of the $P_{\mathrm{r}}$ promoter of bacteriophage $\lambda . E M B O$ Journal 1, 1217-1224. 